INOBIS: Jurnal Inovasi Bisnis dan Manajemen Indonesia

Volume 2, Nomor 1, Desember 2018

Muhammad Naufal Makarim

\title{
The Effect of Spectator-Based Brand Equity on Behavioral Intentions in Football Club
}

\author{
Muhammad Naufal Makarim \\ Department of Management, Universitas Indonesia, Jakarta, Indonesia \\ naufal.makarim@gmail.com
}

\begin{abstract}
Purpose - The purpose of this paper is to find out the effect of Spectator-Based Brand Equity on Behavioral Intentions in Football Club.

Design/methodology/approach - The research is descriptive in nature that used survey data in the form of questionnaire from 100 respondent from each sample.

Findings - The model developed in this study identifies that social interaction, team success, and internalization were the significant positive predictors of behavioral intentions among the overall sample. These findings highlight the importance of studying different types of consumers and suggest managerial implications, such as the need for clubs to establish reciprocal relationships with fans in order to increase their levels of internalization and contribute to increased behavioral intentions.
\end{abstract}

Research limitations/implications - This research only focuses on perception from Indonesian football fans towards major European football club and might not be representative of other football leagues in Europe and around the world.

Originality/Value - This research offers a framework that can help football club managers plan marketing strategies to approach different segment of customers.

Keywords - Brand equity, Behavioral intentions, Football fan club

Paper type - Research paper

\section{Introduction}

Football is the most popular sport in the world. Its proven the 2014 FIFA World Cup which became the largest sports competition with 3.9 billion viewers from around the world. In the final stage FIFA World Cup 2014 only, the match between Germany and Argentina has witnessed by 700 million pairs of eyes. The total number of followers/fans of the football reached 4 billion people. The dominance of football in the world should no longer be a surprise because this sport is very easily accessible by various society. The equipment needed to play football is also very simple, just a ball and two pairs of legs only (TotalSportek.com, 2017).

"The Beautiful Game" many people call football with this term, from the eastern states like Japan to the western states like America but nothing can match the popularity of this foot sport in Europe. Football almost always dominates sports headlines in some major European countries such as Britain, France, Germany, Spain and other countries. In Latin American countries, football is more than just a game, because it represents the dreams and joy for kids in Latin America (TotalSportek.com, 2017).

Indonesia became the country with the most football fans if it refers to the percentage of Facebook Fan Page from third of the football club with the most supporter in the world. Real Madrid are ranked first with more than 105 million fans worldwide, 9.4\% of the total 
INOBIS: Jurnal Inovasi Bisnis dan Manajemen Indonesia

Volume 2, Nomor 1, Desember 2018

\section{Muhammad Naufal Makarim}

Real Madrid fans come from Indonesia with 9,968,609 fans. Then followed by Barcelona fans who do not differ much from Real Madrid with 103 million fans, but the percentage of Barcelona fans who come from Indonesia increased slightly than the Real Madrid fans who also came from Indonesia at $9.6 \%$ or 9.969 .946 fans. In the third position is Manchester United, from a total of 73 million fans as much as $13.3 \%$ came from Indonesia. There is a significant increase in Manchester United fans that fans from Indonesia dominate Manchester United fans up to two-digit percentage (SocialBakers.com, 2017).

As can be concluded together, in the three football clubs with the most fans in the world, the largest number of fans always comes from Indonesia on each team. The data further reinforces that Indonesia has the largest fan base for elite football clubs in Europe based on statistical reviews on Facebook Fan Page. The next finding is not only Indonesia as the biggest fan contributor to the big football clubs in Europe, but fans from Indonesia are showing increasing trend from time to time. The upward trend is fairly consistent although not very significant but it is very promising for other European football clubs if they want to increase their fan base quickly by targeting Indonesian fans.

Football fever in Indonesia in 2017 is increasingly crowded because 58\% of football fans in Indonesia watch more football matches than the previous year (Football-Inc.com, 2017). In addition, $70 \%$ of football fans in Indonesia are more passionate with football than the previous year (Football-Inc.com, 2017). Indicating football continues to be a very interesting entertainment for Indonesian citizens whether consumed alone or together with friends or family. This is reflected in how Indonesian fans watched a football game which is $51 \%$ more with families and 50\% with friends (Football-Inc.com, 2017).

As previously described, European football became a phenomenon in Indonesia. Millions of people from Sabang to Merauke have also made fan clubs to demonstrate their passion for football. Moazzam Malik as the British Ambassador to Indonesia has thought that football fans in Indonesia could be one of the answers to economic problems in several cities in the UK. Over the years, football fans in Indonesia have consistently shown support for big clubs in Europe by making live match screening and selling merchandise. Meanwhile, football fans in Indonesia continue to growth for supporting football clubs abroad (IndonesiaExpat.biz, 2017).

Visits from European elite football clubs are also almost every year in Indonesia which usually will against Indonesian Nationonal Team or football stars from Indonesia. Knowing the power of football fans in Indonesia, Moazzam Malik said it would be a perfect strategy to strengthen relations between the two countries (Indonesia and UK). What is more interesting is that there will be economic growth in both countries if this can happen. Looking at some data and interest from football fans in Indonesia, Moazzam Malik thinks that this is more than likely to be done together (IndonesiaExpat.biz, 2017). As quoted from LiverpoolEcho.co.uk, 2017 "There is so much potential in this market through football, not only encourage the development of football but also encourage other business cooperation with a wider scope".

Such as Garuda Indonesia which has cooperated with Liverpool Football Club in the form of sponsor which Garuda Indonesia logo will be displayed in training uniform from Liverpool Football Club. Moazzam Malik also said from football there will be a greater cooperation such as between the city of Liverpool and Surabaya which is said to be a benchmark for the city of Surabaya to learn about ports, advance manufacturing, and creative industries. Moazzam Malik has also spoken with the Mayor of Surabaya, Mrs. Tri Rasmaharini to discuss further about the cooperation that can be established between 
INOBIS: Jurnal Inovasi Bisnis dan Manajemen Indonesia

Volume 2, Nomor 1, Desember 2018

\section{Muhammad Naufal Makarim}

Surabaya and Liverpool which eventually the Mayor scheduled to visit Liverpool in the near future (LiverpoolEcho.co.uk, 2017).

There has been some research that suggests managing brand equity is a vital measure for professional sports clubs in order to generate long-term benefits (Bauer, Sauer, Schmitt, 2005, Ross, 2006, Teed, Delpy-Neirotti, Johnson, \& Seguin, 2009) A professional sports club has the potential to build brand equity by leveraging the psychological relationship with fans (Couvelaere \& Richelieu, 2005) .This research tries to fill the gaps between previous studies which want to know how a football club brand is perceived by fans who do not is incorporated with membership of a fan club with fans who are members of fan club membership in one of the biggest football fan base in the world, namely Indonesia.

\section{Theoretical Background}

\subsection{Fan club membership}

The central idea in relationship marketing theory is the continuity of customer relationships, from transactional to relational oriented (Gravald \& Gronroos, 1996; Magnusen, Kim, \& Kim, 2011). This idea is very important in sports scenarios considering that clubs have different types of fans ranging from those watching occasional games, fans who buy products or services from clubs, as well as fans who pay a fixed and regular fee (ie, fan club members) have the privilege related products and services from the club (McDonald $\&$ Shaw, 2005). Fan club membership becomes very important for sports clubs because this strategy can generate a stable source of income for the club (Biscaia, Correia, Menezes, Rosado, \& Colaco, 2012; McDonald \& Shaw, 2005). In line with previous statements, professional sports clubs are becoming an example of membership-based organizations (McDonald \& Stravos, 2007), and some European football clubs can be a good illustration of this important strategy.

However, it is important to note that fan club members are different from season ticket holders. Season ticket holders buy some sort of package to have access to all or nearly all team games at the stadium at an affordable price, but he does not need to be involved in a membership program. Fan club members on the other hand, pay a fixed and periodic fee to have various benefits associated with clubs, goods, and other offered services that go beyond simple seasonal ticket holdings. Another important benefit for the club is that when fans engage in membership programs, their personal contact information is included into the club's database. This allows strategies that will be developed by organizations to strengthen the relationship between clubs and fans through direct marketing methods and targeted promotions.

\subsection{Sport brand equity}

Brand equity refers to " additional utility or value added to products with their brand names " (Yoo, Donthu, \& Lee, 2000, p.195). Brand equity measurement is a key topic in branding research, with the conceptual framework proposed by Aaker (1991) and Keller (1993) representing a major theoretical basis for developing brand equity models in different industries (Kayaman \& Arasli, 2007; Pappu, Quester, \& Cooksey, 2005; Yoo \& Donthu, 2002). Aaker (1991) created the concept of brand equity as a combination of brand awareness, brand associations, perceived quality, brand loyalty, and brand assets. In Aaker (1991) model, Keller (1993) introduced the concept of costumer-based brand equity (CBBE) 
INOBIS: Jurnal Inovasi Bisnis dan Manajemen Indonesia

Volume 2, Nomor 1, Desember 2018

\section{Muhammad Naufal Makarim}

consisting of two components: brand awareness and brand image. The CBBE model highlights the customer's knowledge of the brand as a key driver in creating brand equity, and this approach has provided useful insights into how a sports manager controls the audience's mental associations towards their team (Bauer et al., 2008; Gladden \& Funk, 2002).

In the context of sports, brand equity has been described as the consumer value embedded in the names and symbols of their favorite teams (Gladden \& Milne, 1999). The idea of managing teams as a brand has become a common paradigm in the sport marketplace (Doyle, Filo, McDonald, \& Funk, 2013; Gladden \& Funk, 2002). Some researchers are developing scales to measure brand equity over the last decade in various sports sports (Bauer et al., 2005; Biscaia et al., 2013; Gladden \& Funk, 2001; Ross et al., 2008). However, most research only develops scales based on the theoretical foundations proposed by Aaker (1991) and Keller (1993), and does not consider audience experience in their favorite teams (Bauer et al., 2005; Gladden, Milne, \& Sutton, 1998; Gladden \& Milne, 1999; Marticotte \& Carrier, 2009). Failure to incorporate audience experience in the conceptualization and operation of brand equity sports is a potential limitation in understanding overall brand equity in the context of audiences (Ross, 2006).

\section{Method}

\subsection{Data collection and sample}

Data for this study were collected through an online survey placed on the instant messaging network. With the support of the fan club coordinator, the questionnaire was distributed through group chat and also explaining the purposes of the study and inviting visitors to access a survey link about their favorite team. The email address was recorded and further access from these email addresses was denied after the survey submission in order to avoid repeat participants. The survey was available online for about seven non-consecutive days with a total of 307 visitors accessing the survey link. The data were examined and responses from surveys not fully completed and those containing 10 or more consecutive answers on the same scale number were excluded from further analysis. After these data screening procedures, 200 surveys were deemed usable for data analysis for an effective response rate of $65.1 \%$. Although using an online survey was based on the benefits of higher response rates, reduced overall costs, and improved design capabilities (Bech \& Kristensen, 2009), it is important to note that this type of survey may limit the representativeness of the sample. The final sample included fans of all 16 teams from 4 leagues, and almost all respondents were males (88.7\%). Ages of the respondents ranged from 18 to 50 years, with the greatest majority $(85 \%)$ being less than 30 years old. More than half of the participants $(81,7 \%)$ had a college or post-graduate degree. Almost half $(49.3 \%)$ reported going to the stadium in the company of two or three other persons. More than one-third (36.2\%) had expenses Rp1.000.0001 - Rp3.000.000, yet less than one-fifth (19.2\%) were watched football games with 4 people or more.

\subsection{Measures}

The online survey included items used to assess brand equity and behavioral intentions, alongside the above-mentioned sociodemographic questions. Brand equity was assessed using the 30-item scale proposed by Biscaia et al. (2013) and includes brand associations and internalization measures. The use of this scale was due to the fact that it was developed in the 
INOBIS: Jurnal Inovasi Bisnis dan Manajemen Indonesia

Volume 2, Nomor 1, Desember 2018

\section{Muhammad Naufal Makarim}

football context and has previously showed adequate construct validity. Brand associations were assessed through 27 items representing brand mark, social interaction, commitment, team history, organizational attributes, team success, head coach, management, and stadium. Internalization was also assessed through the inclusion of three items, and all scale items were measured on a 7-point Likert-type scale, anchored by 'Strongly Disagree' (1) and 'Strongly Agree' (6). The behavioral intentions measure included three items, two being derived from Yoshida and James (2010), and one adopted from Zeithaml, Berry, and Parasuraman (1996). These items were also measured on a 6-point Likert-type scale, but ranging from 'Strongly Disagree' (1) to 'Strongly Agree' (6).

\subsection{Data analysis}

The processing and analysis of data that has been collected will be explained more comprehensively in this section. This research uses multiple linier regression method or multiple regression to analyze data. Number of respondents required in at least 100 respondents. In accordance with the tori developed by Hair et al. (2009) that the number of sample sizes should be greater than or equal to 100 (one hundred).

According to Priyatno (2014) linear regression analysis is an analysis used to predict dependent variables with one or more independent variable values. When the independent variable is more than one then the method is multiple regression. Multiple linear regression analysis used in this study aims to determine the effect of 10 independent variables namely brand mark, social interaction, commitment, team history, organizational attributes, team success, head coach, management, stadium and internalization to the dependent variable behavioral intentions.

\section{Results}

Then, in the table coefficients that have been summarized in table below shows the significance value of ten independent variables. The significance value for each variable is broken down into two parts consisting of fan club members (FCM) and non-fan club members (Non-FCM) samples. In this study the limit value for the value of $t$ is 1.64 because the hypothesis testing is one-way with a $95 \%$ confidence level. For Brand Mark variables on fan club members (FCM) sample have significance value $\geq 0.05$ that is 0,179 and value of $\mathrm{t} \leq$ 1,64 that is equal to 1,353 . The non-fan club members (Non-FCM) have a significance value of 0.786 and a $t$ value of 1.013. Based on the value of significance and $t$ value on both samples $\mathrm{H} 0$ is accepted. 
INOBIS: Jurnal Inovasi Bisnis dan Manajemen Indonesia Volume 2, Nomor 1, Desember 2018

Muhammad Naufal Makarim

\begin{tabular}{|c|c|c|c|c|c|c|}
\hline $\begin{array}{l}\text { Dependent } \\
\text { Variable }\end{array}$ & $\begin{array}{l}\text { Independent } \\
\text { Variable }\end{array}$ & Sample & $\begin{array}{c}\text { Unstandardiz } \\
\text { ed } \\
\text { Coefficients } \\
\text { B }\end{array}$ & $\begin{array}{c}\text { Standardize } \\
d \\
\text { Coefficients } \\
\text { Beta }\end{array}$ & $\begin{array}{c}\mathrm{T} \\
\text { value }\end{array}$ & Sig \\
\hline \multirow{2}{*}{\multicolumn{2}{|c|}{ (Constant) }} & $F C M$ & $-2,300$ & & $-0,841$ & 0,403 \\
\hline & & $\begin{array}{l}\text { Non- } \\
\text { FCM } \\
\end{array}$ & 1,021 & & 0,424 & 0,673 \\
\hline \multirow{20}{*}{$\begin{array}{l}\text { Behavioral } \\
\text { Intentions }\end{array}$} & \multirow{2}{*}{ Brand Mark } & $F C M$ & 0,169 & 0,138 & 1,353 & 0,179 \\
\hline & & $\begin{array}{l}\text { Non- } \\
\text { FCM } \\
\end{array}$ & 0,120 & 0,111 & 0,273 & 0,786 \\
\hline & \multirow{2}{*}{$\begin{array}{l}\text { Social } \\
\text { Interaction }\end{array}$} & $F C M$ & 0,002 & 0,002 & 0,022 & 0,982 \\
\hline & & $\begin{array}{l}\text { Non- } \\
\text { FCM } \\
\end{array}$ & 0,191 & 0,238 & 3,564 & 0,001 \\
\hline & \multirow{2}{*}{ Commitment } & $F C M$ & 0,076 & 0,072 & 0,758 & 0,450 \\
\hline & & $\begin{array}{l}\text { Non- } \\
\text { FCM }\end{array}$ & $-0,024$ & $-0,018$ & $-0,174$ & 0,862 \\
\hline & \multirow{2}{*}{ Team History } & $F C M$ & 0,002 & 0,001 & 0,016 & 0,988 \\
\hline & & $\begin{array}{l}\text { Non- } \\
\text { FCM } \\
\end{array}$ & $-0,023$ & $-0,042$ & $-0,074$ & 0,941 \\
\hline & \multirow{2}{*}{$\begin{array}{l}\text { Organizational } \\
\text { Attributes }\end{array}$} & $F C M$ & 0,080 & 0,082 & 0,854 & 0,395 \\
\hline & & $\begin{array}{l}\text { Non- } \\
\text { FCM } \\
\end{array}$ & $-0,028$ & $-0,028$ & $-0,261$ & 0,795 \\
\hline & \multirow[b]{2}{*}{ Team Success } & $F C M$ & 0,093 & 0,099 & 0,969 & 0,335 \\
\hline & & $\begin{array}{l}\text { Non- } \\
\text { FCM }\end{array}$ & 0,364 & 0,664 & 2,160 & 0,033 \\
\hline & \multirow{2}{*}{ Head Coach } & $F C M$ & $-0,032$ & $-0,073$ & $-0,670$ & 0,504 \\
\hline & & $\begin{array}{l}\text { Non- } \\
\text { FCM }\end{array}$ & $-0,097$ & $-0,094$ & $-0,718$ & 0,475 \\
\hline & \multirow{2}{*}{ Management } & $F C M$ & 0,127 & 0,171 & 1,873 & 0,064 \\
\hline & & $\begin{array}{l}\text { Non- } \\
F C M \\
\end{array}$ & $-0,008$ & $-0,009$ & $-0,075$ & 0,940 \\
\hline & \multirow{2}{*}{ Stadium } & $F C M$ & 0,220 & 0,191 & 2,046 & 0,044 \\
\hline & & $\begin{array}{l}\text { Non- } \\
\text { FCM } \\
\end{array}$ & 0,139 & 0,110 & 0,601 & 0,549 \\
\hline & \multirow{2}{*}{ Internalization } & $F C M$ & 0,390 & 0,405 & 4,717 & 0,000 \\
\hline & & $\begin{array}{l}\text { Non- } \\
\text { FCM }\end{array}$ & 0,342 & 0,306 & 3,721 & 0,000 \\
\hline
\end{tabular}


INOBIS: Jurnal Inovasi Bisnis dan Manajemen Indonesia

Volume 2, Nomor 1, Desember 2018

\section{Muhammad Naufal Makarim}

Variable Social Interaction on fan club members (FCM) sample significance value of 0.982 and $t$ value of 0.022 indicating that $\mathrm{HO}$ is accepted. Whereas in non-fan club member sample (Non-FCM) Social Interaction variable indicates $\mathrm{H} 0$ is rejected due to its significance value $\geq 0.05$ is 0.001 and the value of $t \leq 1.64$ is 3.564 . The Commitment variable shows the same thing as Brand Mark variable, where in both samples H0 is accepted. The significance value is 0.450 and the value of $t$ is 0.758 in the fan club members (FCM) sample and the significance value is 0.862 and the $t$ value is -0.174 in the non-fan club members (Non-FCM) sample.

The significance values of 0.988 and 0.815 and the $t$ values of 0.016 and -0.235 from the Team History variables on both samples also indicated that $\mathrm{H} 0$ was accepted. Likewise, the Organizational Attributes variable whose $\mathrm{HO}$ is accepted on both samples has significance value and t value of 0.395 and 0.586 respectively and 0.854 and 0.546 respectively.

Similarly, Team Success variables and Head Coach, H0, both variables are rejected on non-fan club members (Non-FCM) samples because they have a significance value of 0.033 for Team Success variables and 0.044 for Head Coach variables. Similarly the value of $t$ of these two variables is more than 1.64 that is 2,996 for Team Success variables and -2,041 for Head Coach variable. While in the two variables are the same but from different samples of fan club members (FCM), H0 is accepted.

Conversely, Management variables show different results, where the significance value of 0.064 and 0.062 and the value of t equal to 1.873 and 1.889 so that $\mathrm{H} 0$ accepted in both samples. The next variable is Stadium which between the two samples has difference of result. In the sample fan club members (FCM) H0 was rejected with a significance value of 0.044 and a value of 2.046. Non-fan club members (Non-FCM) sample at Stadium variable has a significance value of 0.285 and a $t$ value of 1.075 so that $\mathrm{H} 0$ is accepted.

The last variable is Internalization being the only one that $\mathrm{HO}$ is rejected on both samples. Having a significance value of 0,000 and 0,000 and $t$ values of 4,717 and 3,721 make the Internalization variable the most different variable from the nine other independent variables.

Thus, it can be concluded that in this study on the sample fan club members (FCM) there are two independent variables that have a significant positive influence of Stadium and Internalization of Behavioral Intentions variables. While the remaining eight variables are Brand Mark, Social Interaction, Commitment, Team Histroy, Organizational Attributes, Team Success, Head Coach and Management do not have a strong enough influence on Behavioral Intentions variables.

The second conclusion is that in non-fan club members (Non-FCM) samples, there are four independent variables that are proven to have a significant positive influence on Social Interaction, Team Success, Head Coach, and Internalization variables on dependent variable Behavioral Intentions. So the six other variables are considered not to have a significant influence on the dependent variable.

\section{Discussion}

The results provide important implications for professional soccer club managers by providing evaluation and analytical tools to help manage the club's brand to maintain and foster strong relationships with the club's fans. While previous research has suggested the main need of a professional sports club to manage its brand equity in order to remain financially protected (Teed et al., 2009). 
INOBIS: Jurnal Inovasi Bisnis dan Manajemen Indonesia

Volume 2, Nomor 1, Desember 2018

\section{Muhammad Naufal Makarim}

It has been suggested that brand equity contributes to the financial performance of the organization (Kim \& Kim, 2003), and the measurement of brand equity is crucial to understanding the objectives, mechanisms and especially the direct impacts of marketing activities undertaken (Reynolds \& Phillips, 2005, p 171). Therefore, understanding the effect of brand equiy on behavioral intentions to connect with fan club members and non-fan club members. The existence of financial pressures faced by the club in general, as well as increasing competition among clubs in the open market. Sports marketers need to understand which of the 10 most powerful Spectator-Based Brand Equity (SBBE) variables influence the behavioral intentions of the fans in order to develop a marketing strategy that aims to increase the brand value of the club, and to engage fans on club activities, such as attending more games, watching more games, and purchasing other products or services offered by professional football clubs (Theodorakis et al., 2013; Yoshida, Gordon, Nakazawa, \& Biscaia, 2014). Thus, through testing the SBBE model of behavioral intentions in fan club members and non-fan club members it will broaden the understanding of professional soccer club managers regarding SBBE variables among different types of customer a football club.

The only variable from SBBE that significantly influences behavioral intentions in both fan club members and non-fan club members is internalization. Internalization occurs when the fan of a particular sport feels a high degree of conformity to the sports club. This causes one to combine the values and actions of a sports club into one with their own life values (Inoue \& Kent, 2012). Considering that brand awareness is usually high for sports such as soccer because of its worldwide popularity (Bauer et al., 2008; Pyun, Kwon, \& Lee, 2011), internalization seems to have an important role to manage brand equity (Biscaia et al., 2013; Ross et al., 2008) thus affecting the behavioral intentions of both fan club members and nonfan club members. Thus, the club should try to build mutual relationships with fans to ensure they feel valued and keep supporting the team during the season (Couvelaere \& Richelieu, 2005). For example, by holding a quiz or challenge for fans who are rewarded to watch the game live in the stadium with the accommodation being financed. Another way to appreciate the fan is to hold a photo exhibition from fans around the world that will be featured on the football club's main field. The hope the football club can create a higher level of conformity value between fan and football club.

The second strongest influence of one of the SBBE variables on behavioral intentions is social interaction in groups of non-fan club members. Therefore, it is suggested that the club highlights aspects of togetherness that can be intertwined among fellow fans with more organized activities that can be a meeting place of the fans. A simple example is to hold a movie together in big games that are treated to a variety of merchandise sales and games that can be played fan at the time before the game or at halftime. Another thing to do is bring in teams from football clubs to hold matches with local soccer stars. If it is difficult to bring directly the core team, it can bring legend players who have retired.

Internalization has been shown to have a significant and positive influence on behavioral intentions in both groups of fan club members and non-fan club members in Indonesia. These findings add to empirical evidence in the context of the use of SpectatorBased Brand Equity (SBBE) in Indonesia that confirm previous research (Biscaia et al., 2016). The concept of Spectator-Based Brand Equity (SBBE) proposed by Ross (2006) associated with behavioral intentions by Biscaia (2016) has proven to be minimal in effect with only two of the ten variables present in SBBE in fan club members. No different, in the group of non-fan club members there are three of ten variables affect the behavioral intentions. 
INOBIS: Jurnal Inovasi Bisnis dan Manajemen Indonesia

Volume 2, Nomor 1, Desember 2018

Muhammad Naufal Makarim

\section{Limitations and future research}

Further research can add back concessions to further deepen the analysis and see if the experience of watching the game directly in the stadium will affect the behavioral intentions of the Indonesians. For example by way of visiting respondents who are Indonesians living in Europe. Further research can examine Spectator-Based Brand Equity (SBBE) with its eleventh dimensions in soccer league in Indonesia. Further research can examine whether there is any change in effect on SBBE to behavioral intentions before one is joined in fan club members and afterwards. Further research can examine the effect of SBBE on behavioral intentions based on more specific age range. Respondents, in this case more dominated by millennials, can be further classified by segmentation of respondent groups currently in the age range of children, adolescents, and adults. This study examines the effect generally without separating the fan of a particular football club. Subsequent research can examine whether there are differences in influence and assessment on homogeneous respondents (a supporter from just one football club).

\section{References}

Aaker, D. A. (1990). Brand Extensions: The Good, the Bad, and the Ugly. Sloan Management Review, 31(4), 47-56.

Bauer, H. H., Sauer, N. E., \& Schmitt, P. (2005). Customer-Based Brand Equity in the Team Sport Industry. Operationalization and Impact on the Economic Success of Sports Teams. European Journal of Marketing, 39(5/6), 496-513.

Biscaia, R., Ross, S., Yoshida, M., Correia, A., Rosado, A., \& Marôco, J. (2016). Investigating the role of fan club membership on perceptions of team brand equity in football. Sport Management Review, 19(2), 157-170. https://doi.org/10.1016/j.smr.2015.02.001

Boulding, W., Kalra, A., Staelin, R., \& Zeithaml, V. A. (1993). A Dynamic Process Model of Service Quality: From Expectations to Behavioral Intentions. Journal of Marketing Research, 30(1), 7-27.

Branvold, S. E., Pan, D. W., \& Gabert, T. E. (1997). Effects of Winning Percentage and Market Size on Attendance in Minor League Baseball. Sport Marketing Quarterly, 6(4), 35-42.

Brown, T. J., Barry, T. E., Dacin, P. A., \& Gunst, R. F. (2005). Spreading the Word: Investigating Antecedents of Consumers' Positive Word-of-Mouth Intentions and Behaviors in a Retailing Context. Journal of the Academy of Marketing Science, 33(2), 123-38.

Couvelaere, V., \& Richelieu, P. (2005). Brand Strategy in Professional Sports: The Case of French Soccer Teams. European Sport Management Quarterly, 5(1), 23-46.

Djatmiko, C. (2017). Can Indonesian Football Fans Boost this UK City's Economy? Retrieved November 29, 2017, from http://indonesiaexpat.biz/topreads/can-indonesianfootball-fans-boost-uk-citys-economy/

Fournier, S. (1998). Consumers and their brands: Developing relationship theory in consumer research. Journal of Consumer Research, 24(4), 343-373.

Ghoshal, S., Korine, H., \& Szulanski, G. (1994). Interunit Communication in Multinational Corporations. Management Science, 40, 96-110.

Gladden, J. M., Milne, G. R., \& Sutton, W. A. (1998). A Conceptual Framework for Assessing Brand Equity in Division I College Athletics. Journal of Sport Management, 
INOBIS: Jurnal Inovasi Bisnis dan Manajemen Indonesia

Volume 2, Nomor 1, Desember 2018

Muhammad Naufal Makarim

12(1), 1-19. https://doi.org/10.1123/jsm.12.1.1

Gupta, A. K., Govindarajan, V., \& Malhotra, A. (1999). Feedback-Seeking Behavior within Multinational Corporations. Strategic Management Journal, 20, 205-22.

Hayes, J. R. (1995). As Long as It's Free . . Forbes, 72-73.

Henderson, P. W., \& Cote, J. A. (1998). Guidelines for Selecting or Modifying Logos. Journal of Marketing, 62, 14-30.

Houghton, A. (2017). Liverpool FC Indonesia support could bring investment to the city. Retrieved November 29, 2017, from http://www.liverpoolecho.co.uk/news/liverpoolnews/liverpool-fc-indonesia-support-could-12593426

Jackson, A., Hall, D., Moss, C., \& Tracy, S. (2017). The Football Inc. Fan Index 2017.

Kohli, C., Sari, R., \& Thakor, M. (2002). Creating Effective Logos: Insights from Theory and Practice. Business Horizons, 45, 58-64.

MacInnis, D. J., Shapiro, S., \& Mani, G. (1999). Enhancing Brand Awareness Through Brand Symbols. Advances in Consumer Research, 26, 601-608.

Miller, D. W., Foust, J. E., \& Kilic, O. (2007). An analysis of financial services brand marks. Journal of Financial Services Marketing, 11(3), 257-267. https://doi.org/10.1057/palgrave.fsm.4760051

Morrow, D. J. (1992). An Image Makeover. International Business, 5(3), 66-68.

Nahapiet, J., \& Ghoshal, S. (1998). Social Capital, Intellectual Capital and the Organizational Advantage. Academy of Management Review, 23(2), 242-66.

Parasuraman, A., Zeithaml, V. A., \& Berry, L. L. (1996). The Behavioral Consequences of Service Quality. Journal of Marketing, 60(2), 31-46.

Ross, S. D. (2006a). Development of a Scale to Measure Team Brand Associations in Professional Sport. Journal of Sport Management, 20, 260-279. Retrieved from http://search.proquest.com/docview/288208437?accountid=14495\%5Cnhttp://diana.uca .es:4550/resserv?genre $=$ dissertations $+\&+$ theses $\&$ issn $=\&$ title $=$ The + development + of $+a+$ scale+to+measure+professional+sport+team+brand+associations $\&$ volume $=\&$ issue $=\& d$ ate $=2003-01-01 \&$ atitl

Ross, S. D. (2006b). for Understanding Spectator-Based Brand Equity Conceptualizations of Brand Equity. Journal of Sport Management, 20(22), 22-38.

Ross, S. D., Russell, K. C., \& Bang, H. (2008). An Empirical Assessment of Spectator-Based Brand Equity. Journal of Sport Management, 22, 322-337. https://doi.org/Article

Social Bakers Editor. (2017a). Facebook statistics of Sport Club pages | Socialbakers. Retrieved November 29, 2017, from https://www.socialbakers.com/statistics/facebook/pages/total/sport/sport-club/

Social Bakers Editor. (2017b). FC Barcelona in Indonesia | Facebook page statistics | Socialbakers. $\quad$ Retrieved November 29, 2017, from https://www.socialbakers.com/statistics/facebook/pages/detail/197394889304-fcbarcelona? country=indonesia

Social Bakers Editor. (2017c). Manchester United in Indonesia | Facebook page statistics | Socialbakers. $\quad$ Retrieved November 29, 2017, from https://www.socialbakers.com/statistics/facebook/pages/detail/7724542745manchester-united?country=indonesia

Social Bakers Editor. (2017d). Real Madrid C.F. in Indonesia | Facebook page statistics | Socialbakers. $\quad$ Retrieved November 29, 2017, from https://www.socialbakers.com/statistics/facebook/pages/detail/19034719952-realmadrid-c-f?country=indonesia

Total Sportek Editor. (2017). 25 World's Most Popular Sports (Ranked by 13 factors). 
INOBIS: Jurnal Inovasi Bisnis dan Manajemen Indonesia

Volume 2, Nomor 1, Desember 2018

\section{Muhammad Naufal Makarim}

Retrieved November 29, 2017, from http://www.totalsportek.com/most-popular-sports Tsai, W. (2002). Social Structure of "Coopetition" within a Multiunit Organization: Coordination, Competition, and Intraorganizational Knowledge Sharing. Organization Science, 13(2), 179-90.

Wakefield, K. L., \& Sloan, H. J. (1995). The effects of team loyalty and selected stadium factors on spectator attendance. Journal of Sport Management, 9, 153-172.

Waltman, N. L. Z. (1988). The development and validation of an instrument measuring attitudes, subjective norms, and behavioral intentions of nurses toward dying patients and their families. The University of Nebraska. Retrieved from https://remotelib.ui.ac.id:6066/docview/303566401/fulltextPDF/B565AEFCB00C44E8PQ/18?accou ntid $=17242$ 